\title{
A cline of enregisterment and its erasure: Intersections of ideology and technology in minority-language news
}

\author{
K A T H R Y E. G R A B E R \\ Indiana University Bloomington, USA
}

\section{A B S T R A C T}

Audiences often ascribe monolithic linguistic authority to news media institutions, viewing journalists as the bearers of language standards. Yet media are in fact heteroglossic, with journalists across different media platforms negotiating competing practical demands and different understandings of the social purposes and possibilities of their work. This article examines a case of hyperideologized minority-language media to show how the interplay of deep-seated language ideologies, the local sociohistorical context of media, and the material, technological affordances of different platforms produces a cline of enregisterment. It focuses on media produced in Buryat, a Mongolic language of southeastern Siberia whose speakers are shifting to Russian. Comparing journalists' linguistic practices and audiences' interpretations across the coexisting media platforms of newspapers, radio, and television shows how media enregisterment and, in turn, the enregisterment of a standard literary language occur along a cline that is shaped by the intersections of ideology with technology. (Media, language ideology, enregisterment, standardization, purism, materiality, Russia, Russian, Buryat)*

\section{N T R O D U C T I O N}

$T s k$, $t s k$. Tsètsėgma made a clicking noise with her tongue and shook her head. We were watching television in her living room, and Tsètsėgma, a Buryat woman in her forties, was criticizing a young television reporter for mixing too much Russian into his Buryat-language report. I asked whether she could give any examples. "Well I don't know", she said. "He just doesn't speak in the literary language. He's justwell, he's young, and he just doesn't speak really excellently, not like, for example... Bator". "'Yeah, Bator!", one of the other people present, a younger man named Dugar, exclaimed. "He speaks the literary Buryat language beautifully. You know, he worked for the newspaper for a long time. He knows all the ancient Buryat words and... he speaks like that on television. He raises the level of the language".

(C) The Author(s), 2021. Published by Cambridge University Press. This is an Open Access article, distributed under the terms of the Creative Commons Attribution-NonCommercial-NoDerivatives licence (http://creativecommons.org/licenses/by-nc-nd/4.0/), which permits non-commercial re-use, distribution, and reproduction in any medium, provided the original work is unaltered and is properly cited. The written permission of Cambridge University Press must be obtained for commercial re-use or in order to create a derivative work. 0047-4045/21 $\$ 15.00$ 
Bator produces news in Buryat, a northern Mongolic language with 326,500 self-reported speakers concentrated in Russia, Mongolia, and China (Eberhard, Simons, \& Fennig 2020). Buryat once dominated southeastern Siberia and is now the titular language of the Russian Federation's semiautonomous Republic of Buryatia, but generations of speakers have been shifting from Buryat to Russian, and the future of the language is unclear. Between the 2002 and 2010 allRussian censuses, the proportion of the Republic of Buryatia's Buryat population reporting knowledge of Buryat fell from $81 \%$ to $43 \%$, or 122,882 speakers (Graber 2020:228). Yet speaking Buryat is a strong marker of ethnonational identity and vitality supporting the republic's tenuous sovereignty, and in the 'alternative market' (Jaffe 1999:110) of the minority language public, a purist, standard literary Buryat (SLB) is highly valued. Buryat has a lively presence in the sphere of news media, where its use is guaranteed by republic legislation. In this context, minoritylanguage journalism has become a bastion of linguistic and cultural standards, a hyperideologized domain of practice to which Buryats orient as the source not only of trustworthy and authoritative information, but also of correct ways of speaking and being Buryat. Journalists like Bator have become crucial brokers of Buryat linguistic and cultural reproduction in the midst of more general Russification. Thus Tsètsėgma and Dugar emphasized journalists' responsibility to hold the line against Russian encroachment, and they singled out Bator as a particularly successful stalwart.

What was curious about their assessment was that Bator DIDN'T speak "like that" on television. Transcripts of Bator's recent programming did not reveal the "ancient words" that Dugar identified. In fact, Bator's reports were markedly Less purist than the reports of many of his junior colleagues. I had learned, in the course of workplace observation and interviews at the television station where Bator worked, that he routinely excised purist literary choices, such as Buryat neologisms and complex, bookish-sounding clauses, from junior journalists' scripts, favoring Russian borrowings and colloquialisms instead. Archived media texts showed that he had changed his linguistic practices as he had moved, over the course of his career, from newspapers to radio to television.

These differences were obscured from the view of Tsètsėgma and Dugar, watching television in Tsètsėgma's apartment. To everyday consumers of news media, media institutions often appear as monolithic arbiters of linguistic authority, acting on a 'prescriptive imperative' (Cotter 2010:40) and speaking in a unified news media register, if not in a generally standard register. In fact, however, media producers may engage in varied linguistic practices. Buryat-language media, as a hyperideologized set of practices, show this variation very clearly. In the context of language shift, how media institutions negotiate the balance between Russian and Buryat takes on significance for the fate of the languagewith the relevant balance being not only between two codes, Russian and Buryat, but also 'within' Buryat, in a range of overlapping ways of speaking at varying stages of enregisterment. Other scholars of efforts to decolonize language through purification have likewise found media personnel and cultural activists 
negotiating a balance between more purist and less purist registers, most notably Wertheim $(2003,2006)$ in her discussion of the more and less Russified forms of Tatar used in Tatarstan (Russian Federation) and Swinehart (2012) in his explication of register formation among Aymara-language radio broadcasters in Bolivia. My argument here is that even within a community of media practitioners, the negotiation along this scale of purism varies, and it varies systematically by media platform. Across different platforms, journalists manage translation, reported speech, codeswitching, and other language contact phenomena differently. Likewise they evince different understandings of the social purposes and possibilities of their work.

This article examines a cline of enregisterment in minority media by comparing journalists' linguistic practices and audiences' interpretations across coexisting media platforms. Data are drawn from field research conducted in multiple periods over 2005-2011, integrating production and audience studies with linguistic analysis of media texts. During field research, I was based in Ulan-Ude, a city of 404,426 people (Burstat 2010) and the capital of the Republic of Buryatia. Findings are supplemented by my additional research in more rural districts of the republic and the nearby Buryat territories of Ust'-Orda (in Irkutsk Oblast) and Aga (in Zabaikal'sk Krai).

In the production study, I interviewed journalists and conducted workplace observation at sixteen different media institutions, shadowing reporters when possible and following the editing process. Journalists often wanted to interview me to showcase a foreigner's interest in Buryat, and reciprocal interviewing became one of my research methods. In 2008-2009, I surveyed thirty-six journalists working in bilingual newspaper, radio, and television offices to produce a demographic snapshot of Buryat-language media workers and compare the experiences of workers specializing in Buryat versus Russian media production. Additionally, I interviewed correspondents and retired journalists who had previously worked at these institutions and at an additional four district and republic newspapers, bringing the total sample of local institutions represented in the production study to twenty. In this article, I focus on news reportage produced by the Republic of Buryatia's flagship state-run newspaper, Buriaad Ünen (The Buryat Truth), and broadcasting company, the State Television and Radio Broadcasting Company 'Buryatia' (BGTRK) - both because news reporting is a hyperideologized domain of linguistic practice and because this is where the bulk of Buryat-language media is produced.

The audience study consisted primarily of informal interviewing and participant observation within households: observing people's media practices, watching television together, discussing the news and other programming, and documenting media circulation and access. Ultimately, I observed media practices and conducted informal interviews in approximately sixty households. These households were not selected systematically, and because I relied heavily on invitations through personal networks, the sample was biased toward Buryat and Buryat-speaking families. The sample was also skewed by gender, with approximately sixty-five percent women to 
thirty-five percent men, reflecting my easier access to women in domestic contexts and the country's gender imbalance. ${ }^{3}$ However, because I was able to conduct research in multiple districts, across rural and urban communities, and through multiple unrelated contacts, the sample was diverse in terms of other demographic factors, including educational and income levels. Late in my research, after observing differential intelligibility across Buryat media platforms, I conducted a series of five audience focus groups in Ulan-Ude to document this phenomenon more systematically. Having built a corpus of media texts, I selected six samples, two each for newspapers, radio, and television, that were produced around the same time in 2009 by Buriaad Unèn and BGTRK and that represented typical but varied topical genres of local news reportage (medical, political, religious, human interest, etc.) and voices (a young man, a doctor, a shaman, the president, a career journalist, etc.). I then submitted the same samples in the same order repeatedly to speakers with self-reported knowledge of Buryat, who were recruited through public signage and informal networks, in focus groups and interviews. In groups of one to three, focus group participants read newspaper articles, listened to radio clips, and watched television clips, then discussed the language used within them, along with general issues in Buryat language and media, over two to three hours. Although focus group participants were all currently living in Ulan-Ude and self-selected to be personally interested in Buryat language and cultural politics, they roughly reflected regional demographics by age and gender, they had grown up in different rural districts, and they showed a wide range of Buryat linguistic knowledge. In sum, they represented the target audience that most journalists described, and they evinced opinions consistent with findings from my larger ethnographic study (Graber 2020).

The three main sections of this article deal respectively with the three platforms in which Buryat news is produced and distributed: newspapers, radio, and television. The subsections provide four different ways of encountering and analyzing language in media: (i) by looking at the general use of a platform in daily life, ethnographically; (ii) by examining media texts and transcripts, focusing on the language used independently of its contexts of production and reception; (iii) by observing audiences and eliciting responses to that language from audiences, focusing on reception, consumption, or uptake; and (iv) by observing newsroom practices and eliciting explanations from journalists, focusing on production. Methodologically, this makes it possible to see a media platform's total linguistic role in society, rather than privileging the perspective of producers or consumers, and see the media ideologies and language ideologies that tie together its production, textuality, and reception (see also Vidali 2010).

What emerges, as we see below, are the kinds of discrepancies suggested by Tsètsègma and Dugar's assessment of Bator. While journalists hold some language ideologies in common, unique linguistic practices proceed from each medium's material demands and specificities. This is not to say that technology simply DETERMINES language use, but rather that the material conditions of each technology help 
shape the language ideologies 'native' to each medium. Media enregisterment and, in turn, the enregisterment of the standard literary language occur along a cline that is shaped by the technological affordances of different platforms.

\section{TECHNOLOGY AND IDEOLOGY IN}

E N R E G IS T E R M E N T

While processes of enregisterment may proceed through un-mass-mediated talk (e.g. Poedjosoedarmo 1968; Schilling-Estes 1998; Johnstone, Andrus, \& Danielson 2006), mass media are an especially productive site for studying enregisterment. This is because, as Agha (2005:38) has argued, registers 'are not static facts about a language but reflexive models of language use that are disseminated along identifiable trajectories in social space through communicative processes' (see also Agha 2007). Mass media provide precisely such communicative possibilities and, insofar as we as analysts can access media texts in the form of newspaper articles and recorded broadcasts, give us a way to trace the trajectories of these reflexive models of language use as well. Media are not, however, mere 'carriers' (Agha 2004:38) for registers; they are precisely where those registers are worked out. At the intersection between technology and ideology, mass media are productive sites of negotiation for fixing the linguistic forms of registers, abstractable and extractable for later use elsewhere.

Preliminarily, we might observe that newspapers, radio, and television provide different technological affordances. Originally developed in design and perception studies, this concept refers to the social possibilities granted by a technological artifact when used for its intended purpose (Gibson 1977; Norman 1988; Hutchby 2001). ${ }^{4}$ Newspapers, for example, offer a more fixed version of speech than an ephemeral radio broadcast, and they are more readily available to be shared and passed around over time. Those material facts are already shaped by historical processes - paper was unavailable in Buryatia during World War II, for example - and the intended purpose is already dependent on the technology's social context. In one sociocultural context, the medium that best fosters social practices of media consumption and metacommentary may be newspapers, such as in Tamil tea shops, where men actively discuss current events (Cody 2011). In another sociocultural context, such as contemporary Buryatia, that social role is better fulfilled by television, viewed by families together in living rooms. The historical and social context-dependence of what might otherwise appear to be exclusively materially determined affordances is captured in scholarship on media ideologies. Media ideologies are a counterpart to language ideologies (Gershon 2010), drawing our attention to how assumptions about language may be authorized and reinforced (or disrupted) by the material specificities of a given medium.

Media ideologies can pick up and extend language ideologies by matching particular registers to particular media platforms and further regimenting their social use. For instance, Kunreuther (2014) has documented an intimate radio register 
used by disc jockeys in post-democratic Nepal. This is not unlike Ferguson (1983) describing a discrete register of sports announcer talk, but Kunreuther further shows how such a register, developed and extended through FM radio, is relevant far beyond the narrow community of broadcast professionals who use it. Rather, this media register is implicated in the political ecology of a newly democratic society, in which an ideology of directness figures prominently. A narrative of selfrecognition is reinforced, in that context, through dual attention to developing one's voice as an expression of interior selfhood and the use of FM radio, a medium locally experienced as immediate, transparent, and direct. By thus unpacking the relationships between sociopolitical circumstances, the lived material qualities of particular media platforms, and expectations for language use, we can place a media register within a broader ecology of speech. Let us first consider that broader context by examining the SHARED goals and ideologies of minoritylanguage journalists who nonetheless engage in divergent practices.

SHARED GOALS AND IDEOLOGIES OF

M I N O R I T Y - L A N G U A G J O UR N A L I S M

At any given time, there are approximately thirty-five journalists producing material partly or wholly in Buryat. ${ }^{5}$ As a group, they share some basic goals and ideologies, some of which are held in common by professional journalists more generally and others of which are specific to their work as a minority elite. Like majority-language journalists, they follow a double logic in pursuing both immediacy, minimizing attention to the medium (i.e. 'we are speaking directly to you', 'live from the scene', eyewitness accounts, etc.), and hypermediacy (mastheads, bylines, 'in the studio', 'catch more of the latest news at our website', etc.) (similarly see Bolter \& Grusin 1999). They also imagine their work to be at least partially dialogic with their projected AUDIENCE but deemphasize their dialogism with interviewees - minimizing, that is, their part in shaping a source's words. These compulsions follow from an assumption of professional journalistic objectivity that will seem familiar to consumers of English-language news, though post-Soviet journalism is not nearly as enamored with the ideal of objectivity as US or western European journalism has been (Mickiewicz 2005; Roudakova 2017:122).

Yet the goals of minority-language journalists are also unique. In contrast to the writers and editors of Russian-language newspapers in Buryatia, who tend to speak of their societal roles in terms of "enlightenment" and "informing the public", the writers and editors of Buryat-language publications talk about their role as being primarily one of linguistic and cultural "preservation" (sokhranenie) or "development" (razvitie), which they pursue through minority-language media's symbolic and pedagogical functions. Their embrace of the symbolic function of Buryatlanguage media in Buryat society can be seen in their heavy emphasis on genres of history and culture, with less content in the 'hard news' genres of politics, economics, investigative reporting, and social analysis. Treating their craft as a 
pedagogical tool comes almost as second nature because a high percentage of Buryat-language journalists were trained as schoolteachers. Newspapers run popular children's pages with games, puzzles, and stories focusing on language learning and cultural education. BGTRK produced a popular series of Buryat language lessons through songs, targeting adults, and posted them to YouTube.

More subtly, journalists working across platforms share a strong language ideology holding Russian and Buryat separate, defining articles and stories as essentially "Russian" or "Buryat", not both, and eschewing "mixing" on general principle. The standard for journalists working in Buryat is nearly always SLB, based on the Khori dialect of Buryatia's eastern steppes. Although its standardization and implementation have been incomplete, SLB is widely treated as the apotheosis of Buryat ethnonational development, according to a very strong post-Enlightenment language ideology opposing a well-developed, institutionalized literary standard to dialects and colloquial ways of speaking (Graber 2017, 2020; see also Shagdarov 1967, 1974). Among journalists producing news media in Buryat, two general principles follow from this. First, USE RusSIAN-ORIGIN FORMS AS LITTLE AS POSSIBLE. This principle is evident in the use of neologisms, proactive excavation and reintroduction of existing Buryat or Mongolic words, and treatment of reported speech, which will be 'cleaned up' in whatever way the medium allows. Second, uSE Dialectal Forms as litTle AS POSSIBLE. There is little doubt that Buryat-language media are more easily comprehended when they incorporate dialectal forms, but standard-bearing cautions against it. This, however, is one of the many ways in which linguistic practices differ across platforms. Such differences become more apparent by examining each of the three main media-newspapers, radio, and television - in turn.

\section{NEW S A PERS: PEDAGOGICAL PURISM IN PRINT}

The fixity and ubiquity of newspapers raise the public profile of the minority language, while also encouraging journalists to adhere strictly to standards. Relative to broadcast media platforms such as radio and television, newspapers 'fix' language in a concrete, recorded format that can be returned to by readers or passed from reader to reader. Writers capitalize upon this durability when they emphasize the pedagogical potential of the medium, assuming their readers can 'consume' a story in Buryat more than once and therefore using the most purist and most complex choices from SLB, with minimal concern for reader comprehension.

Newspapers are also ubiquitous, visible and useful in daily life even to nonspeakers of Buryat. In this highly literate society, busy newspaper kiosks hum with social activity. Newspapers provide an important source of time-sensitive information on events, including religious services (primarily Buddhist, shamanic, and Orthodox), public holiday celebrations, and astrological predictions. Other uses to which Buryat-language newspapers are put do not require that a person 
actually read the newspaper. They serve the symbolic function of having the language textualized; writing packages the language into a manipulable symbol that is available in the visual channel for comment even by (non)readers who otherwise have no access. Also, the SUBSTANCE of newspaper is put to uses besides reading. The women I lived with stored tomatoes from their summer gardens in cardboard boxes beneath their sinks, each tomato carefully wrapped in newspaper to last from August until February, when it might be served for the lunar new year. Wrapping fish and sausages, covering plates of offerings, protecting houseplants, packaging snacks to sell on the street, and wrapping Buddhist texts were all common everyday uses of newspaper as a material substance. In these ways, newspaper carries materialized language into nooks and crannies of daily life where it otherwise might not appear.

\section{The language of newspapers}

Newspapers with Buryat-language material manage the relationship between Buryat and Russian in different ways. Some district newspapers produce a Russianlanguage weekly or monthly with a second, smaller Buryat-language version as a periodic insert; others intermix Russian and Buryat content in a unified publication. Both Buriaad Unėn and another major Buryat-language paper, Tolon (Ray of Light), have introduced policies to include Russian-language articles, comprising as much as one-third of the total content. They are carefully framed, however, as Buryat-language newspapers, with administrative notes and contact information translated into Buryat, and Mongolian-scripted transliterations of the titles in the mastheads.

Much of the text of Buriaad Unèn is translations, such as required Buryat translations of official proclamations from public officials who conduct most of their business in Russian. In this role, the newspaper is home to an official style of Buryat, calqued from Russian (specifically Soviet Russian) style. The former president's many holiday proclamations, for example, began with 'Respected friends!' Khủndètè nủkhèdủủd!, a common form of address used in formal ceremonies and toasts that is modeled on (Soviet) Russian Uvazhaemye tovarishchi! 'Respected comrades!'. Similarly, the punctuation convention of formal direct address in Russian is borrowed by capitalizing formal/plural second-person pronouns ( $\mathrm{R}$. $V y$, B. Ta).

Outside of official proclamations, most newspaper stories cover topics culturally relevant to a Buryat minority public, such as local history, visual and performing arts, human interest, Buddhism, and shamanism. Some of the traditions covered are currently being revitalized, such that writers do not expect their readers to know all the Buryat terms. For example, in a Buriaad Unen article reporting a conversation between journalists and a well-known Buryat shaman, the shaman details the meanings of several Buryat animal totems. Some of them, such as the Blue Wolf 
(Bürte shono), are prominent figures of Buryat mythology that a Buryat audience can be expected to know, so they go unmarked in the Buryat text. Others, however, are more obscure. For the Variegated Burbot (Ėreèn gutaar) totem, the writer gives a gloss in Buryat, zagahan, indicating that the Ėreèn gutaar is a type of fish. (The fish referenced is Lota lota, a freshwater member of the cod family native to Lake Baikal.) In the same article, the Buryat term hakhiuuha(n) is glossed as totem, and a sacred shamanic spot on Baikal's Ol'khon Island is glossed with the Russian name by which it is most famous, mys Shamanka. Here journalists use simple Buryat and Russian asides as pedagogical tools to (re)teach Buryat.

Other important features of the language of newspapers lie in syntax and morphology, such as long sentences and participial phrases. The first sentence of the same sample story exemplifies a characteristic feature of newspaper prose in its sheer length, as shown in (1).

(1) Excerpt from the article 'Tėngèri', published in Buriaad Unèn (The Buryat Truth), February 2009.

2 Shèné Komushkadaa (ul. Barnaul'skaia,

3 164' 'a') óóryngóo bodoto gazar dèré

4 tủbkhinèhèn'Tèngèri' gèhèn bỏỏ

5 shazhanai èmkhiin baishan haiakhan orozho

6 erèmsėėrèè, khanaarn' dèère ùlgègdèhèn

7 zuraguudye kharan, zhurnalistnuudta

8 khöörèzhẻ baihan tus èmkhiin tủrüủlègshè,

9 pedagogikyn èrdèmëi kandidat, mèdèèzhè

10 bỏó, 'Buriaad ùnèn-Dủkhėrigèi'

11 èmkhidkhèdèg'Buriaadai tủrủu khủnủủd -

12 2007' gèhèn konkursyn laureat Bair

13 Zhambalovich TSYRENDORZHIEVAI

14 tailbarinuudye shagnababdi.

\section{'[We] having just arrived at the} building of the shamanic organization called 'Tèngèri', which has settled in New Komushka (Barnaul'skaia street, 164a) in its own concrete location, and looking at the pictures hung on its wall, speaking to journalists was the chairman of this organization, candidate of pedagogical science, well-known shaman, [and] laureate of the competition called 'Best

People of Buryatia-2007' organized by

Buriaad Ünèn-Dükhèrig, Bair Zhambalovich TSYRENDORZHIEV, to whose observations we listened.'

Notice the long series of nested participial and gerundial phrases leading up to a simple verb at the end, shagnababdi 'we listened'. (Buryat's word order is SOV.) The construction depends, like much newspaper prose, on elaborate participles, verbal adverbs, and other complex verb morphology (in boldface above). They include rare gerundial verb forms like that in line 6, -msaar/-msoor/ -msèer/-msóor, meaning 'only just' or 'as soon as', that appear only in SLB. 
Another exemplary participle in this article occurs further on, in line 53 in (2).

(2) Excerpt from the article 'Tèngeri', published in Buriaad Unèn (The Buryat Truth), February 2009.

53 'Tẻngèridèn" èmkhidkhẻgdèkhèè baihan 'we talked about contemporary religious 54 münóo ủeyn mürgèlnüùd, ëho gurimuud 55 tukhai khöorèldèbèbdi, ceremonies and traditional rites that will be organized at his 'Tëngèri',

The participle èmkhidkhègdèkhèe is formed from èmkhidkhè(khè) 'to organize':

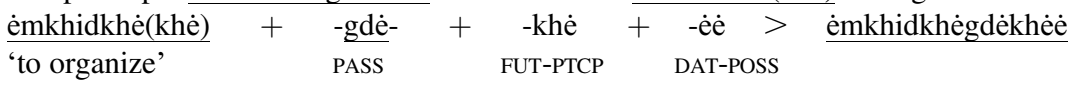

This participle involved a choice. From the active root verb ėmkhidkhèkhè 'to organize', there are multiple possible passive verbs meaning 'to be organized' from which to proceed: ėmkhid(khè), èmkhidè(khè), and èmkhidkhègdè(khè). Note that the writer chose the most complex of the three. An analogy in English might be choosing 'orientate' over 'orient', or 'utilize' over 'use'.

This example illustrates an important point about the language of newspapers: more complex verb morphology typically wins out. While all of the verb forms discussed here may occur in other contexts, they are particularly characteristic of SLB and newspaper prose. Newspaper writing shows a much higher tolerance for complex syntactic constructions than other speech genres, including the radio and television language explored below. This complexity had a profound impact on readers' experiences and their responses to these texts.

\section{Native-speaker assessments}

In focus groups and interviews, the participle discussed above, èmkhidkhègdèkhèe, proved a stumbling block for even the most fluent readers of literary Buryat. Most readers had difficulty with the text of newspapers, which they generally ascribed either to speaking a 'non-literary dialect' or to not having studied Buryat formally in school. Without explicit instruction in the grammar of SLB, the participial phrases and complex constructions used by newspaper journalists proved too much. "I can't read", they would say simply, "because I didn't study it in school".

Given the absolutism of these claims, the specific features that presented difficulty were sometimes hard to determine, but a few emerged as particularly cumbersome. Readers especially complained about the "bookish style" (knizhnyi stil'). Participles like èmkhidkhègdèkhèe appeared needlessly complex; getting to the end of this particular sentence, one girl muttered under her breath, "Oy, horror" (Oi, uzhas). Younger readers also had some difficulty with the Soviet style in the official/political genre, and almost everyone had difficulty with the shamanic terminology in the cultural/religious genre. "You'd only know this if you went to 
NGI!", cried one participant, referring to the National Humanities Institute, institutional precursors of which trained most of the journalists writing for the newspaper. She pointed to her sister, who had performed on stage in Buryat ensembles and "knew these kinds of things".

\section{Writers' reasoning}

Compared with radio and television journalists, newspaper journalists are remarkable for their greater emphasis on their pedagogical role, their intensive use of neologisms and excavated archaic Buryat and Mongolic terms, and their 'cleaning up' of interview material.

They almost uniformly cited their pedagogical role as paramount. This selfunderstanding sometimes leads print journalists to treat their readers as students rather than equals, manifesting an arrogance that risks turning readers away. Some ascribe younger readers' difficulty to a lack of desire, or to laziness. For example, when I reported a focus group participant's low comprehension rate to Minzhur, a Buryat-language newspaper reporter, I expected him to lament the difficult participial phrases, or the nearly insurmountable distances between dialects of Buryat. Instead, he shrugged and said that she should try harder. That's the problem with our young people, he said. They don't try. Minzhur believed that his existing audience consisted basically of older Buryats who already knew the language well, and while he welcomed new readers, he did not seek them out or try to accommodate them.

One of the reasons Minzhur's prose is difficult for Russian-dominant readers to comprehend is that he actively expunges Russian influence by using neologisms and archaicisms. Neologisms, argued one former Buriaad Ünèn reporter, are good for the language and encourage pride among speakers. Newspaper journalists did not, in my experience, regularly invent their own neologisms, but they did appeal to their former teachers and linguists to suggest them, and they have been prominently involved in attempts to create a Buryat language academy on the model of the Académie Française (see also Shagdarov 1967). More often, they excavate and reintroduce Buryat archaicisms. As sources, journalists rely mainly on dictionaries but also on their friends, former teachers, spouses, or parents, and especially grandparents or other older relatives. This means that newspapers are a crucial site in which older spoken forms may (re-)enter the standard literary language, given the imprimatur of print.

Finally, newspaper journalists are unusual in the extent to which they can and do clean up interviewees' speech. It is a fact of Buryat-language print journalism that the overwhelming majority of material is collected in Russian and translated by the journalist, either in-situ while taking notes or later in the conversion of notes into a prose story. In fact, newspaper reporters rarely even attempt to 
elicit quotations in Buryat. In my interviews, journalists reported that they collected most of their material in Russian, and shadowing reporters quickly confirmed this.

Given that journalists EXPECT to translate the raw 'input' of observed events and interviews into original prose, it almost goes without saying that they feel Russian usage in interviews or reported speech can and should be 'cleaned up' and made into fluent Buryat. When I was interviewed for Tolon and Ust'-Ordyn Ünèn (The Ust'-Orda Truth), the reporters seemed charmed that I even suggested that I be interviewed in Buryat. I reminded the reporters that I was not a native Russian speaker anyway; neither language was EASY for me. But ultimately I gave in to the expectation that most people are dominant in Russian, and the fact that, as one of the reporters put it, it was basically the same to them. Indeed, as I spoke in Russian, she recorded our conversation and jotted down notes in Buryat, repeating the elicitation method that I witnessed most often. In this very fast and diffused translation process, little effort is made to retain an individual's voice. It is usually impossible to tell, from a finished product, what language or languages, registers, or conversational forms were employed in the reported utterances. Here the characterological figures usually strategically indexed by the use of voicing (Agha 2005, 2007) are flattened by adherence to register. We all become fluent speakers of SLB in the newspaper.

To summarize, newspaper prose almost definitionally embodies SLB, characteristic features of which include complex syntactic and morphological structure, extensive use of participial and gerundial phrases, overcomplexificationism, neologisms and archaicisms, and accommodation of official styles. Comprehension is low, especially for speakers of non-literary dialects and people with less formal education in Buryat. Many would-be readers find newspapers frustrating, inducing feelings of guilt, shame, and involuntary detachment from their 'native language'. In this sense, the gap between SLB and spoken, everyday language appears to be actively increased by language use in newspapers, in that potential SLB readers do not have sufficient existing knowledge to read (or want to read), thereby missing the chance to gain further knowledge of the literary standard. Newspaper journalists, however, have little immediate reason to accommodate these readers, invested as they are in a language ideology that privileges the strong, unified national literary standard represented by SLB and given a platform that materially showcases it.

\section{R A D IO : A M B IVALENT PURISM}

If newspapers show a strong determinism between the material qualities of the medium and journalists' language choice within it, language use in radio cautions against technological determinism. As we see below, some of the technological affordances and constraints of radio shape linguistic decisions in predictable ways. 
Ephemerality, for example, should encourage the use of more colloquial speech for the sake of immediate comprehension, and the lack of a visual channel should encourage oral fluency. Yet some of the most distinctive features of radio language are at odds with these expectations, reflecting instead journalists' backgrounds and their assumptions about their unique audience: a shrinking number of older Buryats living mainly in rural areas.

Radio is the news source least used by contemporary Buryat-speaking audiences, as documented in both my audience study and a larger survey reported in Badmaeva (2004). In my study, no one under thirty reported regularly listening to Buryatlanguage radio, though they did listen to it by chance, if they "happened to catch [lovit'] it" while at the home of a relative - usually a grandmother or elderly aunt. The narrowness of their demographic perplexed some radio workers. In an interview in 2009, a seasoned radio and newspaper reporter mused, "I don't know exactly why city people [gorodskie] don't listen". Part of the answer lies in the language of radio.

\section{The language of radio}

When radio revolutionized Soviet communication in the 1930s, it promised to bring news media, in the words of a Buryat editor speaking at an editorial meeting in 1962, "closer to life" (blizhe $k$ zhizni), and to bring literary standards and the spoken language closer together - which it did, to an extent (National Archives of the Republic of Buryatia, f. 914, op. 1, d. 8, p. 141). Today, however, the language of radio is also characterized by reporters' heavy use of SLB and native Buryat alternatives to Russian terms, by phonological nativization of those Russian borrowings that ARE used, and by a stark contrast between the prepared texts read by announcers and the more conversational forms employed by interviewees. We can see how some of these features are specific to radio by following the same speakers across the context of different platforms.

Like newspaper writers, radio journalists often employ native Buryat features over more common Russian or Russian-origin features. Radio journalists will sometimes choose, for example, Buryat-origin sonin for 'newspaper', over the more commonly used Russian-origin gazete (R. gazeta), or surbalzhalagsha for 'correspondent', over the more common Russian-origin korrespondent. Both sonin and surbalzhalagsha are Mongolic-origin terms that have been excavated from linguistic history expressly to be substituted for more common Russian-origin alternatives. On the whole, however, radio workers stop short of introducing neologisms. In the sample story excerpted in (3) below, a decorated newspaper reporter is interviewed about his work in Khèzhèngè (R. Kizhinga) district. Note the ambivalent purism on display in this excerpt, in which the journalist introducing him uses Russian-origin items like zhurnalist, tele-, and radio (in boldface below), nativized with Buryat grammatical endings. 
(3) Excerpts from the radio broadcast 'Sagai amiskhal' (Breath of the Times), aired February 21, 2009.

3 Manai teleradiokompaniin

4 surbalzhalagshad Respublikyn prezidentyn

5 shanda khürtèkhyn tủlóo zhurnalistnuudai

6 khoërdokhi kharalgada dakhinaa

7 èrkhimlèbè.

[...]

9 [...] zhèlèi èrkhim radiozhurnalist gèhèn

$[\ldots]$

$11[\ldots]$ gürènèi televideniin zhurnalist

$12[\ldots]$ zhèlèi èrkhim

13 telezhurnalist [...]

14 Buriaad respublikyn araduudai khoorondo

15 kharilsaa gurimshuulkha khèrègtè u̇ürgé

16 nủlỏỏ ủzủủlhẻnèi tủlỏỏ gèhèn nominatsida

17 'Uulzalgyn baiar' gèhèn teledamzhuulga

18 baiguulhan zokhëokhy bülèg èrkhimlèè.

19 Tiikhède Buriaadai radiogoi 'Doloon

20 khonog' gèhèn mèdèèèlèi damzhuulgyn

21 a:vtor Irina Sandakova Iaroslav

22 Gashegai nėrèmzhètè shanda khürtóó.

23 Gèkhè zuura shagnalda khürtègshèdèi

24 nėgèn 'Khėzhėngyn gol' soninoi zhurnalist

25 Bato-Tsėrén Duga:rov bolono.

'Correspondents of our tele-radio company were once again selected to receive awards from the president of the Republic at the second examination of journalists.

[...]

[...] Best Radio Journalist of the Year $[\ldots]$

$[\ldots]$

[...] state television journalist [...] Best

Television Journalist of the Year [...] The creative team that established the television broadcast 'The Joy of Meeting' won a nomination for its role in promoting good relations between the peoples of the Republic of Buryatia.

Also, the author of Buryat radio's informational broadcast called 'Seven Days',

Irina Sandakova, won the Jaroslav Hašek award.

Among the laureates is a journalist of the 'Valley of Khèzhèngè'

newspaper, Bato-Tsèrèn Dugarov.'

While the radio reporter chose the uncommon surbalzhalagsha and sonin in lines 4 and 24, note the use of teleradiokompani in line 3 and zhurnalist in lines 5, 9, 11, 13 , and 24 (in boldface above). Although these latter words entered Buryat through Russian, editors frequently deem such terms 'internationalisms' and allow or even favor them, for reasons discussed below. This short text demonstrates the mixed use of common Russian-origin terms, Buryat grammatical nativization, and the rarer Mongolic substitutions more characteristic of purism. Radio journalists also frequently Buryaticize Russian-origin lexical items and personal names through phonological nativization, such as by applying vowel length, which is phonemic in Buryat, to stressed vowels in Russian. Here this is done in line 21 by lengthening the initial stressed /a/ of Russian avtor to a:vtor and in line 25 by overapplying vowel length to Bato-Tseren Dugarov's name (in boldface above).

In a continuation of this radio broadcast in (4), the newspaper journalist being interviewed, Dugarov, repeatedly uses gazeté, the more common Russian-origin 
alternative for 'newspaper'. He works for Khėzhèngè, a Buryat-language district newspaper that nearly always prints sonin over gazeté. Yet here, on the radio, he says gazeté, in lines $27,33,37$, and 55 (in boldface below).

(4) Excerpts from the radio broadcast 'Sagai amiskhal' (Breath of the Times), aired February 21, 2009.

26 Manai 'Khèzhèngyn gol' [loud bang in

27 background] gézhè gazetèdè olon zon

28 azhalladag. [...]

33 'Khèzhèngè' gazetėmnai buriaad khèlèn

34 dèerè gurban zuun tabin khèhègèer

35 garadag.

36 Orod khèlèn dèèe 'Dolina Kizhingi'

37 gazetėmnai mianga taban zuun khëhègèer

38 garadag lè daa. [...]

55 Saashadaa gazetèmnai khododoo

56 dėlgèrzhè, khủn zonoo uiaruulzha iaazha, [...]

'Many people work at our 'Valley of Khėzhènge' [loud bang in background] newspaper.

[...]

Our 'Khėzhèngè' newspaper is published in the Buryat language [with a print run of] 350 copies. And our 'Dolina Kizhingi' newspaper is published in the Russian language [with a print run of] 1500 copies. [...] In the future, may our newspaper prosper, touch people's hearts,' [...]

This is but one example of how, in radio, interviewees' speech introduces conversational forms into the language of news media. Additionally, while this speaker controls what is known (somewhat oxymoronically) as a 'literary dialect', close to the Khori dialect basis of SLB, many interviewees speak dialects farther from the standard. Incorporating these various non-standard features sets up a contrast between the speech of interviewers and interviewees.

The Khėzhèngè journalist's register choice here underscores his participant role (Goffman 1981) within the radio interview context. As is clear from the newspaper prose that he regularly produces, he controls SLB at the highest possible levelindeed, serving as one of Buryatia's key arbiters of literary standards. His newspaper prose displays many of the features and tendencies described above for newspaper journalism, including complex verb morphology and purist lexical choices. Yet in the role of radio interviewee, he uses forms that diverge from those of his literary labor, including, in the excerpt above, not only gazete but also short sentences; simple, repetitive verb forms (azhalladag 'work (habitually)' in line 28 and garadag 'is published (habitually)' in lines 35 and 38); and a colloquial form, iaazha following a verb, in line 56. He could, presumably, have scripted a text in advance and subjected it to the same editorial process as a newspaper article or broadcaster's script, to be read on air. Instead, he meets a different expectation: that the interviewee will speak spontaneously and bring the broadcast 'closer to life'. 


\section{Listeners' responses}

Focus group participants and interviewees agreed that radio was an authoritative source of "good" Buryat, close to the status of newspapers. Listeners praised the radio announcer and interviewing reporter for their "beautiful", "poetic", formal Buryat, "like what they say on the stage"-meaning in formal events framed in Buryat, such as theatrical performances and beauty pageants. This interpretation likely derived from the journalists' careful enunciation and their (over)emphasis on vowel length and prosodic contours.

But the radio journalists and interviewees alike were difficult to understand, especially for those listeners who also had difficulty with newspaper prose. Most listeners found the Khėzhèngè newspaper reporter, Dugarov, easiest to understand. Some appreciated that he spoke informally, in short sentences that incorporated some Russian, which made his speech accessible to semi-speakers and speakers of non-literary dialects. One embattled listener, who claimed to understand very little of what the other speakers said, expressed gratitude for the announcer's reference to zhurnalistnuud and Dugarov's use of gazeté. At least, she said, she could understand "what the talk was about" ( o chëm idët rech'). Overall, comprehension of radio fell between that of newspapers and television.

\section{From behind the microphone}

Early on, Buryat media producers grasped the uniqueness of radio as a medium, particularly its ephemerality. When a correspondent compared Pravda Buriatii and Buryat radio at a meeting in 1959, an editor objected vehemently that newspaper and radio were two different things. You can read the newspaper again and again, he said, but by radio "they said it [once] and you'll hear it no more" (skazali i bol'she ne uslyshish') (National Archives of the Republic of Buryatia, f. 914, op. 1, d. 5, pp. 5-6).

One might expect that contemporary radio journalists would likewise place greatest emphasis on immediate comprehension. But in fact, in an example cautioning against technological determinism, they stress cultural and linguistic preservation, as achievable through example, pedagogy, and editing. They do so for ideological and sociological reasons. Ideologically, the radio workers I observed and interviewed acted primarily on activist-conservative impulses and were motivated by a kind of pragmatic purism. They mainly expressed this implicitly, through linguistic choices like the phonological and grammatical nativization of Russian-origin material outlined above. Echoing linguistic anthropologists who have found that speakers are more explicitly aware of the lexicon than other aspects of language (Silverstein 1981; Kroskrity 1998), the explicit editorial correction that I observed usually targeted lexical items. Less often, editors corrected syntax and enunciation. One radio worker, for instance, reported being instructed by her editor to use "Buryat pronunciation" for Russian words (interview recorded 2009). When called upon to attend consciously to their linguistic decisions, radio workers emphasized "preservation" (sokhranenie) as their 
main goal, citing instances in which they chose older Buryat terms over recent Russian borrowings. They were also more likely than newspaper workers to selectively employ internationalisms, which they considered preferable to creating neologisms for an unwilling audience. Tele- and televidenie, radio, respublika, zhurnalist, and prezident are all arguably of international rather than RuSSIAN origin, and journalists, if called upon to justify their choices, would stress such words' Latin and Greek roots, emphasizing the deep history of words like televidenie rather than their more recent entry into Buryat through Russian (see also Graber 2019). One editor interviewed in 2009 summarized the (unformalized) language policy at her radio program as: "literary Buryat, unless you can't get around it".

The preservationist bent of Buryat-language radio institutions can also be traced to sociological factors, namely journalists' backgrounds and their projected audience. Most of the radio journalists I surveyed and interviewed had been trained first as teachers and had begun their careers in print journalism. For instance, the radio host featured in the radio samples, Dashidondok Amogolonov, graduated from Irkutsk State University, the training ground of many in the Buryat language elite, and worked at Buriaad Unen before joining the radio station in 1992. Like other radio journalists (Bell 1982), Buryat radio journalists also alter their speech for their projected audience. They know that their audience is primarily rural and older, and they target them with musical programming, history, literature, and human-interest stories. They expect their audience to already command the literary language, which makes a difference not only in how announcers and correspondents script their own language, but also in how they elicit interview material.

The absence of the visual channel means the length and quality of material - that is, recorded sound - is at a higher premium than in newspaper and television interviews. There is little filler to be added, beyond musical interludes, and you cannot distract the audience by intercutting awkward pauses with camera shots of trees. Interviewees, therefore, tend to be highly fluent speakers, generally native speakers of literary dialects. I was an instructive exception. Among the many Buryat-language interviews that I gave across newspapers, radio, and television, the two radio interviews were by far the longest and hardest. Producing sustained stretches of discourse requires both fluency in and comfort with Buryat, which is increasingly uncommon. Radio editors cannot add material to interviews; they can only cut. And they do so, with impunity, to produce more fluent Buryat speech. So, for example, the 'umm's, pauses, and mistakes in my interview for BGTRK were snipped to create 'correct', if stilted, stretches of fluent speech.

Buryat-language radio workers have developed strategies for coping with the difficulty of producing new materials. They use archival materials extensively, which minimizes the need to collect new material, minimizes editing time, and maximizes the use of their small staff - with the effect of incorporating into broadcasts older, 'high-style' standard Buryat with less Russian influence than what is spoken today. They also script everything in advance, as the absence of a camera allows announcers, 
correspondents, and interviewees alike to read. My own interviews took place with the aid of brief notes, and the interviewers coached me - in Russian - between questions in Buryat. These practices bring radio production closer to written standards, despite some journalists' goal of producing 'natural' speech.

\section{TELE VIS I O : FLEXIB LE C OLLOQUIALIS M}

At the colloquial end of this cline of enregisterment, television is by far the most popular media platform for consuming news in Buryatia, as well as in Russia more broadly (Badmaeva 2004; Mickiewicz 2008). Access is nearly total: At least one television was available in every household I visited, and it was not uncommon for even a small apartment to have two or three. Yet some of television's material constraints, namely its ephemerality and the expense of production, limit its use as a tool for language pedagogy. Few residents of Buryatia at the time of this study had television recording devices and services, so broadcast material had to be 'caught' when it was broadcast. Ephemerality encourages simultaneous, social co-viewing, because one cannot share the news with an interlocutor in a materially circulating format the way one might share a newspaper or video link. In Buryatia television news is often viewed socially, especially in family gatherings after dinner, accompanied by ample discussion.

While this daily ritual might provide a setting for speaking Buryat, in fact it often takes place in Russian, even in Buryat-dominant families, because broadcast television is overwhelmingly produced in Russian. A television station is an elaborated institution, each action performed with the aid of many people and a great deal of expensive equipment. In Buryatia, these material constraints, in the context of weak political will and limited socioeconomic power, mean that there is very little Buryat-language programming. Sayan, a man in his twenties fluent in Buryat, aired common complaints when he told me, "From time to time, we watch [Buryat-language television]... But there's so little on the air. Very little" (interview recorded 2009). In his view, the main news programming in Buryat, VESTI-Buriatiia, suffered from the lack of broadcasting time. What he identified as too dry a reportage of facts, with too little commentary, he blamed on the limitations of broadcast time for Buryat-language programming. Indeed, while many people roundly criticized Buryat-language news for its content, they were also quick to point out the time limitations that television journalists faced. Some interpreted the brevity of Buryat-language programming as selfperpetuating, in that there is insufficient time to spark interest IN Buryat-language programming. Further, even the news programs that are framed as Buryat include a great deal of Russian, which has to do with strategies of production: Television broadcasts include long stretches of talk produced by non-journalists, in the form of interviews that tend to be more colloquial than radio interviews and the cleaned-up Buryat quotations in newspapers. At the intersection between these technological factors and an ideological expectation of 'real-life', spontaneous speech, television language incorporates far more non-standard forms. 


\section{The language of television}

While television shares its incorporation of interviewees' speech with radio, interviewees on television are less likely to fluently control SLB. Television news producers rarely compensate for this by subtitling Russian-speaking interviewees in Buryat, due mainly to time limitations; instead, they splice together Buryatlanguage interviews as best they can. Consider the following interview featuring spoken Buryat features, including colloquialisms, simplified syntax, and a common type of borrowing. In (5) a man in his mid-to-late twenties gives an editorial/opinion interview in an employment office that has introduced automated ATM-style kiosks to match people seeking employment to available jobs.

(5) Excerpts from the television broadcast 'VESTI-Buriatiia' in Buryat, aired February 2, 2009.

49 Azhalguii khündèshèg baina. 'It's pretty hard to be unemployed.

/interviewee, in coat and fur hat, standing at touch screen, chewing gum/

50 Mủnóỏ olon zon iigėèd lè Now a lot of people are like

51 azhal bèdèrzhè (..) looking for work (..)

/title on screen: Baatar

Abiduev /

/smiles, looks directly at

52 gèrteè iigèèd lè huunal daa. and like sitting at home. camera/

53 Tiigèed lè minii khèlèkhèdè But like just speaking for

/turns toward screen/

54 óöóól khủündè azhal iigèè

myself, I'm really looking for

55 kharazhail bainab, tozhe.

a particular kind of work, too. / gestures in emphasis/

56 Tiigèed baha azhal bolokho

So then will there be work to

57 ium gú, ùgy ium gú... do, or not?...

58 tiigèed kharazha bainabdi. [...]

so we're looking.

$[\ldots]$

[...]

65 Udo:bno kha ium daa, iigeed It's really convenient, how

66 avtomat dèere khadaa. it's on the machine.

/interviewee standing in

67 ligèè óöóỏ èndè erèed, Like especially just coming

68 kharaad lè iigèed iabakhada... here, just looking, and going

69 (.) like... (.)

same place/

/gestures toward screen with finger, mimicking

70 No, udobno gèkhè bainam. Yeah, I find it convenient.' using the touch screen/

This interviewee's speech immediately appears colloquial compared to that of the anchor and reporter framing his interview. His sentences are short, and sometimes incomplete, and he repeatedly uses simple baina 'to be' verbal construction.

\begin{tabular}{|c|c|c|}
\hline khủndèshèg baina & 'it's pretty hard' & (line 49) \\
\hline$\overline{\text { kharazhail bainab }}$ & 'I'm (really/just) looking' & (line 55) \\
\hline kharazha bainabdi & 'we're looking' & (line 58) \\
\hline gèkhè bainam & 'I find it...' & (line 70) \\
\hline
\end{tabular}


This repetition of baina constructions is so characteristic of spoken Buryat that it is sometimes used to lampoon informal speech. Among other Buryat speakers preparing to be interviewed on television, on different occasions I heard both a linguist and a performer who were to be interviewed specifically comment that they wanted to script their words in advance in order to avoid ending every sentence with baina.

In lines 50, 52, 53, 54, 65, 67, and 68, the interviewee uses variants of iigèed lè, a slangy colloquialism meaning 'really', 'really and so', or 'just exactly', performing a phatic function much like contemporary American English 'like'. He also uses a colloquial way of saying 'yes' or 'yeah': Russian no (line 70) is a colloquial Siberianism for 'yes', sometimes locally called sibirskii da, the 'Siberian yes'. No in line 70, tozhe 'also', 'too' in line 55, and udobno 'convenient' in lines 65 and 70 (in boldface above) are common Russian borrowings that are characteristic of conversational Buryat, and that are not borrowed in order to fill lexical gaps in Buryat. Sometimes they are nativized, such as in this speaker's use of udobno in line 65, lengthening the stressed vowel to udo:bno (but not in line 70).

Although television journalists allow more Russian influence into their texts than print or radio journalists, they do not use udobno, tozhe, or no. These are the kinds of features that are allowed into the language of news media via interviews - specifically, interviews with people who might not command Buryat well enough to give a sustained interview on the radio, but who can appear on screen and say sOMETHING in Buryat. In sum, the language of television is characterized not only by the admission of more dialect features, colloquialisms, 'mixed language', and Russian use - that is, non-standard features - than what is admitted into other media platforms, but also by a stark contrast between the linguistic practices of journalists and those of their interviewees.

\section{Viewers' responses}

In focus groups, viewers found the language of television journalists essentially comprehensible and rarely commented on it. They focused instead on interviewees, in whose speech they found much to criticize. The interviewee in the employment office was interpreted as showcasing "how people really talk" and "mixed language" - of which many Buryat speakers are extremely critical (Graber 2017, 2020). His use of Russian udobno prompted viewers to shake their heads. He had, according to one participant, a "typical knowledge of the lexicon" (tipichnoe znanie leksiki). In point of fact, he did not use a great deal of Russian - no nouns or adjectives, for example, and what he did borrow was from a class of adverbs and discourse markers that MANY Buryat speakers borrow in colloquial speech. One linguist, upon seeing this clip, exclaimed that he spoke "just fine" (normal'no), and even "well" (khorosho). What demonstrates 'typical knowledge' is thus not necessarily speaking with lots of Russian influence but more specifically, speaking SIMPLE Buryat with colloquial expressions that may or may not come from Russian (e.g. iigèed lè, udobno). And 'typical knowledge' might well be 'just fine', even from 
the perspective of a champion of literary standards, if the alternative is not speaking Buryat at all. These assessments show how much more colloquial ways of speaking can enter the cline of media enregisterment via interviewees' speech, while simultaneously making the speech of the journalists, adhering more closely to a literary standard, appear to be the unmarked default.

\section{In the studio}

Observing workplace practices in television news production, primarily at BGTRK in 2009, revealed discrepancies between how audiences perceived and interpreted television news - and the linguistic decisions made therein - and how journalists actually produced the news and explained their own practices. For instance, although television news often comes across as spontaneous and fresh, scripting and editing written texts is a central part of the production process. The fact that the speech of anchors and reporters is so much more linguistically complex than that of their interviewees is due not only to their competence, but also to the fact that journalists script and pre-edit almost all the speech that they ultimately broadcast.

In addition to presentation and performance, Buryat-language television personnel emphasize comprehension. This central concern motivates an (unformalized) principle according to which they make linguistic decisions: EXISTING KNOWLEDGE SHOULD BE SUFFICIENT. This principle means that it is not necessary to replace all instances of Russian lexical influence in Buryat by excavating older Mongolic terms. In contrast to print journalists, television journalists rarely had the time or inclination to consult dictionaries or linguistic treatises. In 2009, there was only one Buryat dictionary in the state TV station's newsroom, an old, outdated, abridged edition missing some pages. They were much more likely to consult one another or to cite a Buryat-speaking source in-the-world, such as someone's grandmother. The same principle means that television workers generally avoid neologisms. As an editor at a television station, Bator, the same journalist whom Tsètsegma and Dugar praised for speaking beautiful, literary Buryat, cut a junior reporter's inventive Buryat neologisms for 'syphilis' and 'sexually transmitted infection' because they were too "twisted" and difficult to understand (Graber 2019). Confronted with a televised public service announcement regarding public health, it is perhaps not surprising that Bator deemed comprehension paramount. But note that this stance against neologisms - and, in fact, the whole principle that EXISTING KNOWLEDGE SHOULD BE SUFFICIENT-is antithetical to the pedagogical function that journalists working in other platforms see themselves as fulfilling, and to the shared goal of upholding Buryat linguistic standards. This pragmatism derives less from the ideological position of the journalists than from the material constraints of television as a medium.

Television journalists specifically emphasize not only comprehension, but IMMEDIATE comprehension, because of the medium's ephemerality and fast rate of 
production and consumption. The speed of television production discourages strict adherence to literary standards because there is little time for retakes or editing, given tight deadlines for producing daily news programming. For BGTRK's evening VESTI-Buriatiia program, for example, reporters had only a few working hours to cobble together materials for a 6 p.m. show. In the material they scripted, they were generally open to conversational forms if those were what came to mind first. Working in the group environment of a newsroom, they also depended heavily on each other to come up with individual words, translations, and turns of phrase, Russian- and Buryat-language journalists alike often asking whomever was listening, "How would you say...?" (Kak skazat'...?), without looking up from their computers. Correspondents recorded their visual materials 'in the field' and then recorded their voiceovers in a sound booth from scripts, with live anchors later introducing the pre-recorded stories during broadcast. Retakes were rare-due to impending deadlines, but also to constant pressure to consume as few resources (tape, digital recording space, the time of the videographer, technicians, etc.) as possible. For all of these reasons, there is less text editing, generally, than in print and radio, and more spontaneity in linguistic practice. In order to be instantaneously comprehensible to audiences, and to quickly produce 'fresh' news, workers need to be able to use dialectal forms, Russiancontact-induced forms, and other colloquialisms that might, on more careful reflection, be excised from SLB.

\section{O N C L U S I O N}

While media institutions often appear to audiences as monolithic arbiters of linguistic authority, the apparent unity of linguistic practice ascribed to 'the media' crumbles upon closer inspection. This article has outlined the different linguistic practices characteristic of news discourse in newspapers, radio, and televisionplatforms that were developed in Buryatia in different historical periods and now coexist as joint arbiters of linguistic authority. Far from embodying a monolithic ideal, the journalists producing Buryat-language news negotiate language ideologies, the local sociohistorical context of media, and the material, technological affordances of different platforms to produce a cline of enregisterment.

In particular, journalists working in different platforms manage the relationship between codes in such a cline. Newspaper writing - with more complex syntactic constructions, neologisms, excavated Mongolic terms, culturally specialized terminology, and features of SLB - is produced by literary workers who act on a sense of responsibility for maintaining high (purist) literary standards - even to the exclusion of some readers' comprehension. For many potential readers, this makes approaching the language of newspapers a daunting task, and a painful reminder that their knowledge of Buryat is somehow insufficient or incomplete. Comprehension is higher in radio and television, particularly television, where journalists are less likely to use neologisms and more likely to accept some resources from outside 
of SLB to meet practical demands, namely instantaneous comprehension in the context of fast production. Interviews in both radio and television introduce new linguistic practices into the 'language of the media' and potentially democratize media discourse in this sense, but the two platforms also demand different kinds of performance, and therefore different kinds of speakers. Radio places a higher premium on solid stretches of recorded speech, thus selecting for highly fluent speakers who use features of SLB, while television places a higher premium on speed and availability, selecting for less fluent speakers who use more dialectisms, colloquialisms, and Russian contact-induced features.

One outcome of the approach taken here is unpacking institutional logics that are otherwise obfuscated; institutions that appear univocal from the outside are revealed to be messy, heteroglossic enterprises from within. For would-be speakers of Buryat, this heteroglossia proves problematic, in that media institutions extend the institutional imprimatur of what 'counts' as Buryat unevenly over different practices, clouding the target of language maintenance and revitalization. For analysts, detailing such heteroglossia is critical for more clearly fixing what we mean when we talk about 'the language of media', or 'a' news register. But it is important for other reasons too, which we can see by returning to Bator.

Bator was close to retirement after having worked in media for twenty-seven years, during which he had moved between print, television, and briefly radio platforms in a fashion typical of Buryat-language journalists. As a newspaper reporter in the 1980s, he had written in high-style SLB, while as a television editor he championed the use of a Russian borrowing for the sake of immediate comprehension. He had decided what was linguistically appropriate in a new media platform, his linguistic practices and even the language ideologies that he evinced changing as he moved from one media platform to another. Those decisions proceeded not only from his personal history and predilections, but also from the technological affordances of the specific platforms in which he worked.

Technological affordances are flexible, to some limited extent; they can be bent to different purposes depending on the ideologically imbricated media landscape. Buryat-language radio journalists, for example, given a medium that is quintessentially oral and would lend itself to embracing the spoken language, choose nonetheless to emphasize literary standards. This should caution us against seeing anything as technologically DETERMINED. But this case does suggest that media-not as mere carriers of registers but as the material sites in which they are worked out-leave their marks on speech. Through enregisterment across multiple media platforms, some features that settle into patterns and become part of a socially powerful register, such as an authoritative news register, do so not because of the authorized speech of a particularly prominent speaker or anything inherent to existing language ideologies, but rather because some material specificities of a platform demanded them.

The audiences discussed here seemed to acknowledge variation-explicitly, when focus groups confirmed differential intelligibility across platforms, and 
implicitly, when Dugar and Tsètsėgma ascribed Bator's knowledge of SLB to his time working in newspapers as opposed to television. Yet in hundreds of interviews and conversations, Buryat speakers referred to 'the language of media' as unitary. At one level, this erasure of linguistic variation (Irvine \& Gal 2000) can be understood as the success of media institutions that have historically presented themselves as ideologically and functionally standard-bearers. But the same audiences applied this logic to a PERSON moving in and out of institutions over time. Viewers, listeners, and readers ascribed to Bator-and to other journalists - total personal agency over language, assuming that he maintained conscious control over ideological stance. This case shows how audiences impose characterological sameness on social actors who in fact engage in different practices, erasing difference in favor of the stability of personhood across communicative contexts.

\section{N O T E S}

*I thank Judy Irvine, Alaina Lemon, Barb Meek, Sally Thomason, participants in the University of Michigan Linguistic Anthropology Lab and the University of Chicago Semiotics Workshop, Emily McKee, Mikaela Rogozen-Soltar, and two anonymous reviewers for their insightful comments on drafts. Fieldwork was made possible by the National Science Foundation under award \#0819031, the Social Science Research Council, the US Fulbright-Hays program, and the University of Michigan.

${ }^{1}$ Transcription of spoken Russian and Buryat examples in this article follows standard spelling for both languages. To maximize consistency between languages, transliteration follows the ALA-LC romanization system for Cyrillic, except for terms and names that have established English-language spellings (e.g. Buryat). Russian appears in italics and Buryat with underlining; when an element could be considered either or both simultaneously, both italics and underlining are used.

${ }^{2}$ Personal names are pseudonyms, except with reference to speakers in media samples. Material quoted from audio recordings or in-situ notes is marked with double quotation marks; paraphrases and quotations that have been reconstructed based on scratch notes and memory do not appear in quotation marks.

${ }^{3}$ In Russia in 2009 , there were approximately 0.86 males to every female; among residents sixty-five and over, there were only 0.46 males to every female (Rosstat 2009).

${ }^{4}$ Since its initial development, technological affordances has been used increasingly within humancomputer interaction and media studies to refer to the possibilities granted by a technological artifact's material properties IN GENERAL, without reference to the creator's or user's intentions. This can unwittingly shift the concept back toward technological determinism.

${ }^{5}$ In 2008-2009, twenty-nine of the thirty-six journalists I surveyed were producing mainly Buryatlanguage material. Buryat-language journalism is roughly comparable to Irish-language journalism in the size of its community of practice, and in many of its goals (see e.g. Cotter 2001/2013).

\section{R E F E R E N C E S}

Agha, Asif (2004). Registers of language. In Alessandro Duranti (ed.), A companion to linguistic anthropology, 23-45. Malden, MA: Blackwell.

(2005). Voice, footing, enregisterment. Journal of Linguistic Anthropology 15(1):38-59.

(2007). Language and social relations. Cambridge: Cambridge University Press.

Badmaeva, Liudmila Vladimirovna (2004). Regional'nye SMI i auditoriia: Osobennosti funktsionirovaniia $v$ period transformatsii rossiiskogo obshchestva (na materialakh Respubliki Buriatiia). Ulan-Ude: East-Siberian State Technological University candidate dissertation. 


\section{A CLINE OF ENREGISTERMENT AND ITS ERASURE}

Bell, Allan (1982). Radio: The style of news language. Journal of Communication 32(1):150-64.

Bolter, Jay David, \& Richard Grusin (1999). Remediation: Understanding new media. Cambridge, MA: MIT Press.

Burstat (2010). Chislennost' postoiannogo naseleniia po munitsipal'nym obrazovaniiam respubliki po sostoianiu na 1 ianvaria (1991-2010). Moscow: GKS Rosstat.

Cody, Francis (2011). Echoes of the teashop in a Tamil newspaper. Language \& Communication 31(3):243-54.

Cotter, Colleen (2010). News talk: Investigating the language of journalism. New York: Cambridge University Press.

(2001/2013). Continuity and vitality: Expanding domains through Irish-language radio. In Leanne Hinton \& Ken Hale (eds.), The green book of language revitalization in practice, 301-11. Leiden: Brill.

Eberhard, David M.; Gary F. Simons; \& Charles D. Fennig (eds.) (2020). Ethnologue: Languages of the world. 23rd edn. Dallas, TX: SIL International. Online: http://www.ethnologue.com; accessed November 2, 2020.

Ferguson, Charles A. (1983). Sports announcer talk: Syntactic aspects of register variation. Language in Society 12(2):153-72.

Gershon, Ilana (2010). Media ideologies: An introduction. Journal of Linguistic Anthropology 20(2):283-93.

Gibson, James J. (1977). The theory of affordances. In Robert Shaw \& John Bransford (eds.), Perceiving, acting, and knowing, 67-82. Hillsdale, NJ: Erlbaum.

Goffman, Erving (1981). Footing. In Forms of talk, 124-57. Philadelphia: University of Pennsylvania Press.

Graber, Kathryn E. (2017). The kitchen, the cat, and the table: Domestic affairs in minority-language politics. Journal of Linguistic Anthropology 27(2):151-70.

(2019). 'Syphilis is syphilis!': Purity and genre in a Buryat-Russian news story. In Elizabeth A. Falconi \& Kathryn E. Graber (eds.), Storytelling as narrative practice: Ethnographic approaches to the tales we tell, 226-52. Leiden: Brill.

- (2020). Mixed messages: Mediating native belonging in Asian Russia. Ithaca, NY: Cornell University Press.

Hutchby, Ian (2001). Technologies, texts and affordances. Sociology 35(2):441-56.

Irvine, Judith T., \& Susan Gal (2000). Language ideology and linguistic differentiation. In Paul V. Kroskrity (ed.), Regimes of language: Ideologies, polities, and identities, 35-83. Santa Fe, NM: School for Advanced Research Press.

Jaffe, Alexandra (1999). Ideologies in action: Language politics on Corsica. New York: Mouton de Gruyter.

Johnstone, Barbara; Jennifer Andrus; \& Andrew E. Danielson (2006). Mobility, indexicality, and the enregisterment of 'Pittsburghese'. Journal of English Linguistics 34(2):77-104.

Kroskrity, Paul V. (1998). Arizona Tewa speech as a manifestation of a dominant language ideology. In Bambi B. Schieffelin, Kathryn A. Woolard, \& Paul V. Kroskrity (eds.), Language ideologies: Practice and theory, 103-22. New York: Oxford University Press.

Kunreuther, Laura (2014). Voicing subjects: Public intimacy and mediation in Kathmandu. Berkeley: University of California Press.

Mickiewicz, Ellen (2005). Excavating concealed tradeoffs: How Russians watch the news. Political Communication 22(3):355-80.

(2008). Television, power, and the public in Russia. Cambridge: Cambridge University Press.

National Archives of the Republic of Buryatia, Ulan-Ude, Russian Federation. Fond 914, documents of the primary Party organization of the Committee on Television and Radio Broadcasting of the Council of Ministers of the Buryat ASSR.

Norman, Donald (1988). The psychology of everyday things. London: Basic Books.

Poedjosoedarmo, Soepomo (1968). Javanese speech levels. Indonesia 6:54-81.

Language in Society 51:4 (2022) 
Rosstat (2009). Demograficheskii ezhegodnik Rossii-2009 g. Online: https://rosstat.gov.ru/bgd/regl/ B09_16/Main.htm; accessed November 2, 2020.

Roudakova, Natalia (2017). Losing pravda: Ethics and the press in post-truth Russia. Cambridge: Cambridge University Press.

Schilling-Estes, Natalie (1998). Investigating 'self-conscious' speech: The performance register in Ocracoke English. Language in Society 27(1):53-83.

Shagdarov, L. D. (1967). Stanovlenie edinikh norm buriatskogo literaturnogo iazyka v sovetskuiu epokhu. Ulan-Ude: BION AN SSSR.

- (1974). Funktsional'no-stilisticheskaia differentsiatsiia buriatskogo literaturnogo iazyka. Ulan-Ude: AN SSSR, Buriatskoe Knizhnoe Izdatel'stvo.

Silverstein, Michael (1981). The limits of awareness. Texas Working Papers in Sociolinguistics, no. 84. Austin, TX: Southwest Educational Development Laboratory.

Swinehart, Karl F. (2012). Metadiscursive regime and register formation on Aymara radio. Language \& Communication 32(2):102-13.

Vidali, Debra Spitulnik (2010). Millennial encounters with mainstream television news: Excess, void, and points of engagement. Journal of Linguistic Anthropology 20(2):372-88.

Wertheim, Suzanne (2003). Language ideologies and the 'purification' of post-Soviet Tatar. Ab Imperio 2003(1):347-69.

(2006). Cleaning up for company: Using participant roles to understand fieldworker effect. Language in Society 35(5):707-27.

(Received 22 October 2019; revision received 8 October 2020; accepted 17 October 2020; final revision received 13 November 2020)

Address for correspondence:

Kathryn E. Graber

Department of Anthropology Indiana University

Frances Morgan Swain Student Building 130

701 E. Kirkwood Avenue

Bloomington, IN 47405-7100, USA graberk@indiana.edu 